\title{
Metal subcellular partitioning determines excretion pathways and sensitivity to cadmium toxicity in two marine fish species.
}

\author{
Le Croizier Gaël ${ }^{1,}{ }^{*}$, Lacroix Camille ${ }^{2}$, Artigaud Sébastien ${ }^{1}$, Le Floch Stéphane ${ }^{2}$, \\ Munaron Jean-Marie ${ }^{1}$, Raffray Jean ${ }^{1}$, Penicaud Virginie ${ }^{1}$, Rouget Marie-Laure ${ }^{3}$, Laë Raymond ${ }^{1}$, \\ Tito De Morais Luis ${ }^{4}$
}

${ }^{1}$ Laboratoire des Sciences de l'Environnement Marin (LEMAR), UMR 6539 CNRS/UBO/IRD/IFREMER, BP 70, 29280 Plouzané, France

${ }^{2}$ Centre of Documentation, Research and Experimentation on Accidental Water Pollution (CEDRE), 715 rue Alain Colas, CS 41836, Brest 29218-Cedex 2, France

${ }^{3}$ Institut Universitaire Européen de la Mer (IUEM), Université de Bretagne Occidentale (UBO), CNRS UMS 3113, 29280 Plouzané, France

*Corresponding author : Gaël Le Croizier, email address : gael.lecroizier@hotmail.fr

\begin{abstract}
:
Subcellular cadmium (Cd) partitioning was investigated in the liver of two marine fish species, the European sea bass Dicentrarchus labrax and the Senegalese sole Solea senegalensis, dietary exposed to an environmentally realistic $\mathrm{Cd}$ dose for two months followed by a two-month depuration. $\mathrm{Cd}$ exposure did not modify $\mathrm{Cd}$ cellular partitioning for either species, refuting the spillover hypothesis. Both species contained most of the $\mathrm{Cd}$ in the detoxifying fraction but displayed different handling strategies. Cd was largely bound to heat stable proteins (HSP) including metallothioneins (MT) in sea bass while Cd was more linked to metal rich granules (MRG) in sole. Whole liver concentrations and subcellular partitioning were also determined for essential elements. The greatest impairment of essential metal homeostasis due to $\mathrm{Cd}$ exposure was found in sole. These elements followed the $\mathrm{Cd}$ partitioning pattern, suggesting that they are involved in antioxidant responses against $\mathrm{Cd}$ toxicity. Cd consumption diminished sole growth in terms of body weight, probably due to lipid storage impairment. During the depuration period, the two species showed contrasting partitioning patterns, implying different pathways for Cd elimination from the liver. In sea bass, MT-bound Cd would be excreted through bile or released into blood, crossing the cell membrane via a protein transporter. In sole, MRG-bound Cd would be sequestered by organelles before being released into the blood via vesicular exocytosis. These distinct strategies in cellular $\mathrm{Cd}$ handling in the liver might account for differential sensitivity to Cd toxicity and differential $\mathrm{Cd}$ excretion pathways between the two marine fish species.
\end{abstract}




\section{Graphical abstract}

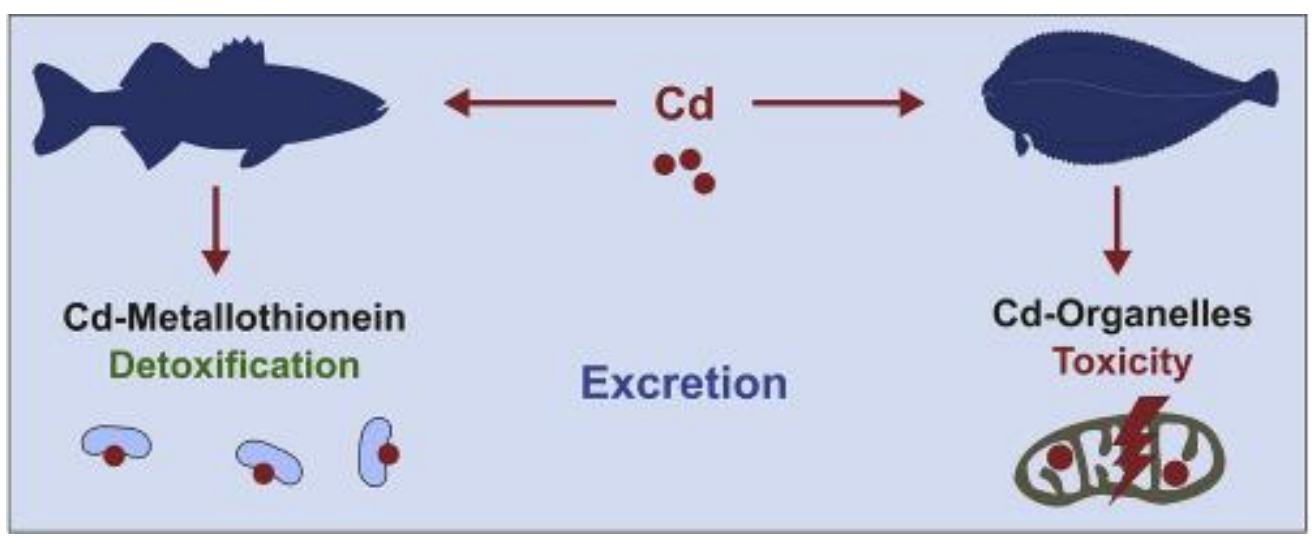

\section{Highlights}

Sea bass and sole displayed different Cd subcellular partitioning in the liver. Cd was largely bound to metallothionein-like proteins in the sea bass liver. $-\mathrm{Cd}$ was mainly linked to metal rich granules in the sole liver. Essential metals followed the Cd partitioning pattern in hepatic cells. Handling strategies might account for sensitivity and Cd excretion.

Keywords : Sub-cellular fractionation ; Dicentrarchus labrax ; Solea senegalensis ; Essential element distribution ; Elimination ; Depuration 


\section{INTRODUCTION}

29 Aside from natural sources, marine ecosystems can be subjected to metal contamination

30 from urban effluents and industrial activities. Cadmium (Cd) is a common by-product of the

31 mining industry and can reach high levels in some regions (World Health Organization,

32 2010). Coastal regions in West Africa, which belong to the Canary Current Large Marine

33 Ecosystem (CCLME), are thereby particularly subjected to $\mathrm{Cd}$ residue due to the direct

34 release of phosphogypsum into water by the phosphate industry (Auger et al., 2015;

35 Cheggour et al., 1999; Gaudry et al., 2007). Marine consumers such as fish mainly

36 accumulate metals through trophic pathway, which can lead to significant $\mathrm{Cd}$ levels in the

37 organs of fish from the CCLME. Moreover, fish species from this region display a wide range

38 of Cd concentrations (Afandi et al., 2018; Diop et al., 2016), resulting partially from

39 differences in foraging habitats and dietary habits (Borrell et al., 2016; Goutte et al., 2015; Le

40 Croizier et al., 2016; Metian et al., 2013). In addition to ecological traits, the observed

41 interspecific variability in terms of $\mathrm{Cd}$ bioaccumulation results from different physiological

42 characteristics, including the presence of metal binding proteins like metallothioneins (MT)

43 (Le Croizier et al., 2018; Moulis et al., 2014; Zalups and Ahmad, 2003). Cd is a toxic element

44 responsible for numerous impairments in fish, such as oxidative damage, disruption of

45 essential metal homeostasis, endocrine and ionoregulatory disruption, histopathology and 
depression of the immune system, which can finally affect growth and survival (McGeer et al., 2011).

Recently, attention has been focused on fish species ability to cope with metal toxicity, depending on subcellular partitioning of the element (Eyckmans et al., 2012; Leonard et al., 2014). At the cellular level, Cd can take different toxic chemical forms including: free or complexed ion forms (e.g. $\mathrm{Cd}^{2+}, \mathrm{CdCl}_{2}$ ), bound to enzymes (e.g. cytochromes), bound to organic acids (e.g. citrates), or bound to cellular constituents causing damages (e.g. DNA) (Vijver et al., 2004). Today, only a few forms of Cd speciation are considered as detoxified: Cd complexed to peptides (e.g. glutathione) or functional, transport or sequestration proteins (e.g. metallothioneins), and Cd trapped in vesicles of the lysosomal system or precipitated in mineral granules (Wang and Rainbow, 2006). Very little is however known about the intracellular mechanisms leading to Cd elimination (Moulis et al., 2014; Zalups and Ahmad, 2003).

While one of the adverse effects of toxic metals is their interference with essential elements (Martelli et al., 2006; Moulis, 2010a), some of them confer a protective role against metal toxicity, directly through formation of detoxifying complexes (Sasakura and T. Suzuki, 1998) or by indirectly preventing oxidative stress due to their association with antioxidant enzymes (Martínez-Álvarez et al., 2005; Talas et al., 2008). The significance of essential element subcellular partitioning in their protective role against toxic metals has never yet been considered. Moreover, despite evidence of the influence of cellular components like MT in metal accumulation kinetics in marine species (Wang and Rainbow, 2010), most previous studies only emphasize on the influence of metal intracellular handling on sensitivity of organisms to toxic elements (Campbell et al., 2008; Eyckmans et al., 2012; Giguère et al., 2006; Leonard et al., 2014; Wang and Rainbow, 2006). Very few studies have therefore 
investigated the link between metal subcellular partitioning and kinetics in fish (Glynn, 1991)

and information about the relationships between $\mathrm{Cd}$ intracellular handling and excretion pathways is lacking for marine fish.

In order to fill these gaps, the present study aimed to investigate $\mathrm{Cd}$ intracellular distribution in the liver of two different marine fish species which are naturally present in the CCLME, a region particularly prone to $\mathrm{Cd}$ contamination. For this purpose, European sea bass Dicentrarchus labrax and Senegalese sole Solea senegalensis, were exposed for two months to an environmentally realistic dietary cadmium (Cd) dose followed by a depuration period of a further two months. Analyses were conducted at the end of the uptake period and at the end of the depuration period and $\mathrm{Cd}$ partitioning was examined in six major subcellular fractions: cellular debris, metal-rich granules, mitochondria, organelles, cytosolic enzymes, cytosolic proteins and peptides, as well as in the storage lipid fraction of the liver when present. Sensitivity of the two species was assessed according to: (1) Cd subcellular partitioning during accumulation and depuration periods, (2) impairments to essential metal subcellular distribution, (3) essential metal concentrations in the whole liver and their partitioning within hepatocytes, (4) growth and hepatosomatic index calculation. Finally, hypotheses were made regarding the influence of $\mathrm{Cd}$ cellular speciation in the liver and $\mathrm{Cd}$ biliary excretion or transport to other tissues.

\section{MATERIALS AND METHODS}

All animal procedures were in accordance with the French and EU guidelines for animal research (project approval number: 03266.03).

\section{Fish and experimental procedures}


All details about animal procedures and experimental design can be found in Le Croizier et al., 2018. Briefly, immature sea bass Dicentrarchus labrax (length: $14.1 \pm 0.7 \mathrm{~cm}$; weight 29.8 $\pm 4.5 \mathrm{~g}$ ) used in this experiment were obtained from a commercial hatchery (Aquastream, Ploemeur, France), whereas immature Senegalese sole Solea senegalensis (length: $14.9 \pm 1.1$ $\mathrm{cm}$; weight $36.4 \pm 7.9 \mathrm{~g}$ ) were provided from a marine farm (Ferme marine de l'Adour, Anglet, France). The fish were transported to the Cedre (Centre of Documentation, Research and Experimentation on Accidental Water Pollution, Brest, France). After receiving anaesthesia by bathing in a $0.05 \mathrm{~mL} \cdot \mathrm{L}^{-1}$ solution of tricaine methanesulfonate (MS-222) (Ackerman et al., 2005), each fish was randomly assigned to one of twelve high density polyethylene tanks that had a $300 \mathrm{~L}$ volume (six tanks for each species, 40 sole and 50 sea bass per tank to ensure equivalent biomass) at the Cedre's marine animal facility. This facility is an independent greenhouse that is submitted to a natural photoperiod and supplied with a continuous seawater flow from the bay of Brest. The temperatures in the experimental tanks followed the outdoor temperature. Fish were first acclimated to the experimental conditions for one month, during which they were fed daily with dried commercial pellets (Turbot label rouge $1.4 \mathrm{~mm}$, Le Gouessant Aquaculture).

To obtain an environmental relevant $\mathrm{Cd}$ concentration in the fish food, a Cd-enriched diet was prepared in order to reach a Cd level around $25 \mu \mathrm{g} \cdot \mathrm{g}^{-1}$, which corresponds to the $\mathrm{Cd}$ level reported in potential prey within the natural distribution of the two fish species (Bodin et al., 2013; Maanan, 2008). For this purpose, the commercial pellets were spiked with a 100 $\mathrm{mg} \cdot \mathrm{L}^{-1} \mathrm{Cd}$ (as $\mathrm{CdCl}_{2}$ in milliQ water) solution for $30 \mathrm{~min}$. The diet was then placed at $-20^{\circ} \mathrm{C}$, freeze dried and broken into small pellets before usage. This preparation led to a $\mathrm{Cd}$ concentration of $22.9 \pm 0.3 \mu \mathrm{g} \cdot \mathrm{g}^{-1} \mathrm{dw}$ in the Cd-enriched food. The control diet was prepared in the same way, but with the addition of millia water only, where the measured 
117 background $\mathrm{Cd}$ level was $0.71 \pm 0.00 \mu \mathrm{g} \cdot \mathrm{g}^{-1} \mathrm{dw}$. For each of the four conditions (i.e., Cdexposed and control fish, for both species) there were three replicate tanks. Dietary Cd exposure was initiated by randomly assigning three of the six tanks per species to the Cdenriched food. The six remaining tanks were fed the control diet. $\mathrm{Cd}$ exposure was conducted for 60 days, after which a depuration period was conducted that lasted for 60 days. During the depuration period, all of the tanks were fed the control diet. Daily food distribution was performed slowly and continuously over $24 \mathrm{~h}$ with a clockwork feeder (COFA, Paris, France) to prevent pellets from remaining in the tank and thus avoid Cd desorption in water. Sea bass were fed at $1.7 \%$ body weight while sole were fed at $1 \%$ body weight per day to meet the physiological requirements of each species (Danion et al., 2011; Salas-Leiton et al., 2010). The bottom of each tank was siphoned every day to avoid Cd leaching from faeces.

Physico-chemical parameters $(\mathrm{O} 2, \mathrm{pH}$, temperature, salinity) and water quality (nitrates, nitrites) were measured every ten days. During the experiment, the water temperature decreased from 20.7 to $12.8{ }^{\circ} \mathrm{C}$, oxygen saturation increased from $81.2 \%$ to $98.2 \%, \mathrm{pH}$ increased from 8.0 to 8.2 and salinity increased from 35.2 to 35.7. The water was free of nitrate and nitrite (Colorimetric test JBL) in both experiments.

\section{Biological sampling}

After the two months of $\mathrm{Cd}$ exposure, three fish per tank (nine for each treatment) were anesthetized by bathing in a $0.05 \mathrm{~mL} \cdot \mathrm{L}^{-1}$ solution of MS-222 before being euthanized by bathing in a $0.2 \mathrm{~mL} \cdot \mathrm{L}^{-1}$ solution of MS-222 (Ackerman et al., 2005). They were weighed, measured and dissected with ceramic tools to avoid metal contamination. The liver was collected, weighed and put in acid-washed $\left(10 \% \mathrm{HNO}_{3}\right)$ individual plastic microcentrifuge 
tubes, flash frozen in liquid nitrogen and stored at $-80^{\circ} \mathrm{C}$ until analysis. Another sampling was

made in the same way after a further two months of depuration.

142

143

144

145

146

147

148

149

150

151

152

153

154

155

156

157

158

159

160

161

162

\section{Subcellular partitioning procedure}

This procedure generally followed the protocol of Rosabal et al. (2015), adapted from that of Wallace et al. (2003), which has been validated and extensively used on various fish species (Campbell et al., 2008; Eyckmans et al., 2012; Giguère et al., 2006; Lapointe et al., 2009a). Briefly, liver samples were fractionated into six operationally-defined subcellular fractions: cell membranes (cellular debris), metal-rich granules (MRG); mitochondria, microsomes + lysosomes (organelles), heat-denatured proteins (HDP) including cytosolic enzymes, and heat-stable proteins and peptides (HSP) such as metallothionein (MT) and glutathione (GSH). Three liver samples of fish from the same tank were pooled to obtain approximately $200 \mathrm{mg}$ of wet sample and homogenized in $1.5 \mathrm{~mL}$ of a solution containing Tris- $\mathrm{HCl} 20 \mathrm{mmol} \cdot \mathrm{L}^{-1} \mathrm{pH}$ 8.6, $0.01 \%$ DTT (dithiothreitol) as a reducing agent and $1 \%$ of an antiproteolytic agent (Protease Inhibitor Mix, GE Healthcare). A $100 \mu \mathrm{L}$ aliquot was removed from the liver homogenate for determining total trace metal concentrations in the liver and assessing metal recovery from the subcellular fractions. The remainder of the liver homogenate was centrifuged at $1450 \times \mathrm{g}$ for $15 \mathrm{~min}$ at $4^{\circ} \mathrm{C}$. The supernatant (S1) was transferred to an acidwashed $1.5-\mathrm{mL}$ polypropylene microcentrifuge tube for further separations. The pellet from this centrifugation was suspended in $0.5 \mathrm{~mL}$ of ultrapure water, heated to $100^{\circ} \mathrm{C}$ for $2 \mathrm{~min}$, digested with an additional $500 \mu \mathrm{L}$ of $1 \mathrm{~N} \mathrm{NaOH}$ at $65^{\circ} \mathrm{C}$ for $60 \mathrm{~min}$. Centrifugation at $10,000 \times g$ for 10 min at ambient temperature $\left(\sim 20^{\circ} \mathrm{C}\right)$ was performed to separate the $\mathrm{NaOH}$ resistant fraction (referred to as "MRG") from the cellular debris fraction, which includes cell membranes, unbroken cells and nuclei. The S1 supernatant was centrifuged at $10,000 \times \mathrm{g}$ for 
163

164

165

166

167

168

169

170

171

172

173

174

175

176

177

178

179

180

181

182

183

184

185

$30 \mathrm{~min}$ at $4^{\circ} \mathrm{C}$ to produce the mitochondrial fraction. The resulting supernatant was ultracentrifuged at $100,000 \times \mathrm{g}$ for $60 \mathrm{~min}$ at $4^{\circ} \mathrm{C}$, giving a pellet containing other organelles (microsomes and lysosomes) and the cytosolic fraction in the supernatant. To separate the heat-stable peptides and proteins (HSP) from the heat-denatured proteins (HDP), the cytosolic fraction was held at $80^{\circ} \mathrm{C}$ for $10 \mathrm{~min}$, left on ice for $1 \mathrm{~h}$ and then centrifuged at $50,000 \times g$ for $10 \mathrm{~min}$ at $10^{\circ} \mathrm{C}$. The HSP fraction, which includes MT, was collected from the supernatant. Each fraction was finally kept at $-20^{\circ} \mathrm{C}$ until the metal analyses were performed.

\section{Metal analyses}

Subcellular fractions were digested in a mixture of $2 \mathrm{~mL} 70 \% \mathrm{HNO}_{3}$ and $0.5 \mathrm{~mL} 30 \% \mathrm{H}_{2} \mathrm{O}_{2}$ (both of ultrapure quality) in closed Teflon vessels. Mineralization was performed on a hotplate for $4 \mathrm{~h}$ at $100^{\circ} \mathrm{C}$. A $100-\mu \mathrm{L}$ aliquot was removed from the digestate and diluted to 15 $\mathrm{mL}$ with Milli-Q quality water (Merck Millipore). Cadmium and essential metals (Ca, $\mathrm{Cu}, \mathrm{Fe}$, $\mathrm{Mg}, \mathrm{Mn}$, Se and $\mathrm{Zn}$ ) were analysed using an ICP Q-MS (X Series 2, Thermo Scientific) at the Pôle de Spectrométrie Océan (PSO, Plouzané, France) with an internal standard solution of Rhodium (2 $\mathrm{\mu g} \cdot \mathrm{L}^{-1}$ ). Reference materials (fish protein DORM-4 and dogfish liver DOLT-5, NRCC) were treated and analysed in the same way as the samples. The results for reference materials displayed mean metal recoveries of $85 \pm 6 \%$ for DORM-4 and $91 \pm 6 \%$ for DOLT-5. Mean recoveries $( \pm S D)$ of DORM-4 reference samples $(n=3)$ were $81 \pm 2 \%$ for $C d, 78 \pm 3 \%$ for $\mathrm{Ca}, 95 \pm 2 \%$ for $\mathrm{Mg}, 89 \pm 5 \%$ for $\mathrm{Mn}, 86 \pm 5 \%$ for $\mathrm{Fe}, 81 \pm 2 \%$ for $\mathrm{Cu}, 79 \pm 1 \%$ for $\mathrm{Zn}, 92$ $\pm 3 \%$ for Se. Mean recoveries ( \pm SD) of DOLT-5 reference samples $(n=3)$ were $99 \pm 2 \%$ for Cd, $83 \pm 1 \%$ for $\mathrm{Ca}, 96 \pm 4 \%$ for $\mathrm{Mg}, 92 \pm 4 \%$ for $\mathrm{Mn}, 98 \pm 6 \%$ for Fe, $86 \pm 3 \%$ for $\mathrm{Cu}, 85 \pm 2$ $\%$ for $\mathrm{Zn}, 86 \pm 2 \%$ for Se. Blanks were included in each analytical batch. The limits of detection (ng. $g^{-1}$ dry $w t$ ), corresponding to the mean concentration of the blank solutions, 
186

187

188

189

190

191

192

193

194

195

196

197

198

199

200

201

202

203

204

205

206

207

were $0.2(\mathrm{Cd}), 1.3(\mathrm{Ca}), 0.4(\mathrm{Cu}), 0.1(\mathrm{Fe}), 0.2(\mathrm{Mg}), 0.01(\mathrm{Mn}), 0.1(\mathrm{Se})$ and $0.4(\mathrm{Zn})$. Total

metal concentrations in the liver $\left(\mu \mathrm{g} \cdot \mathrm{g}^{-1}\right)$ are given on a dry weight basis $\left(\mu \mathrm{g} \cdot \mathrm{g}^{-1} \mathrm{dw}\right)$, based on a previous study involving the same fish and where the liver samples were freeze-dried before analysis (Le Croizier et al., 2018). The proportion of metal in each fraction is expressed as a percentage of the sum of the concentrations of all fractions. As it was not present in all of the liver samples, the storage lipid fraction was not taken into account in the calculation of metal partitioning. Metal proportion in this fraction was expressed as a percentage of the total metal concentration in the liver. "Sensitive fractions" gathered the $\mathrm{Cd}$ contained in the sensitive fractions (i.e. mitochondria + HDP + organelles, while the "metal-detoxified fractions" gathered the Cd contained in the detoxifying fractions (i.e. MRG + HSP) (Eyckmans et al., 2012; Leonard et al., 2014). The total metal concentration recovery in the liver from the sum of the metal concentrations measured in all fractions, including lipids, was $95 \pm 11 \%$ for sea bass and $96 \pm 6 \%$ for sole.

\section{Data analysis}

All data tested statistically were first checked for normality (Shapiro-Wilks tests) (Shapiro and Wilk, 1965) and homogeneity of variances (Bartlett tests) (Bartlett, 1937). When these conditions were met, raw data were used and one-way ANOVAs, followed by Tukey's HSD tests, were performed to test for differences between treatments and species. Otherwise, non-parametric analogues were used, i.e. Kruskal-Wallis tests (KW), followed by ConoverIman multiple comparison tests with Bonferroni's adjustment (Conover and Iman, 1979). All of the statistical analyses were performed using the open source software $R$ (version 3.4.3, $R$ Core Team, 2017). 
RESULTS AND DISCUSSION

\section{Impact of $\mathrm{Cd}$ elimination on $\mathrm{Cd}$ and essential metal partitioning}

After being exposed to cadmium, the two-month depuration period led to many changes in metal partitioning (Table 1).

First, Cd proportion significantly increased in the organelle fraction (from $37.3 \pm 5.9 \%$ to 51.5 $\pm 4.8 \%)$ in sole liver at the end of the depuration period. The organelle fraction includes cellular components involved in the vesicular transport, which is a major pathway for extracellular excretion: Golgi apparatus (GA), endoplasmic reticulum (ER) and lysosomes. ER manages the sequestration of molecules and their binding to excretory proteins, which are transported through the GA and cytosol by vesicles (including lysosomes) and finally excreted across the plasma membrane. Increasing $\mathrm{Cd}$ in the organelle fraction during the depuration period may reflect $\mathrm{Cd}$ exocytosis via vesicles, which could lead to total $\mathrm{Cd}$ elimination from the liver tissue, as described in sole in a previous study (Le Croizier et al., 2018).

Second, Cd exposure followed by a depuration period also led to a displacement of essential elements (Fe, Mg, Mn and $\mathrm{Zn}$ ) from metal rich granules (MRG) to organelles in sole liver (e.g. Fe proportion significantly increased from $30.1 \pm 2.4$ to $41.2 \pm 1.4 \%$ in organelles while it significantly decreased from $16.9 \pm 3.2 \%$ to $9.2 \pm 2.6 \%$ in $M R G)$. In marine organisms, MRG are inorganic insoluble concretions containing mainly Ca phosphate (George et al., 1980), as reflected by the high proportion of $\mathrm{Ca}$ in the MRG fraction in both species $(69.3 \pm 4.1 \%$ and $32.6 \pm 13.7 \%$ for sea bass and sole, respectively, during the depuration period). These structures can play an important role in accumulation and detoxification of metals in fish (Lapointe et al., 2009b; Leonard et al., 2014). 
The simultaneous increase in proportion of $\mathrm{Cd}$ and essential metals in organelles and decrease of essential metals in MRG may be caused by sequestration of MRG by ER, which is part of the organelle fraction (Table 1; Figure 2). This hypothesis seems reasonable since MRG in our species contained the highest proportion of $\mathrm{Ca}$, and ER is deeply involved in $\mathrm{Ca}$ storage (Görlach et al., 2006). Supplementing fish diet has furthermore been shown to increase Cd in MRG while decreasing it in organelles (Ng et al., 2009). Although the authors did not draw this conclusion, our hypothesis is that increasing cellular Ca concentration will reduce the probability for $\mathrm{Cd}$ bound to calcium granules to be sequestered by ER during $\mathrm{Ca}$ uptake. The changes in essential metal cellular repartition would thus be a side effect of $\mathrm{Cd}$ transport from MRG to organelles (i.e. ER, GA and vesicles, in that order) before final exocytosis (Table 1; Figure 2).

Conversely, no change in Cd partitioning was observed in sea bass liver despite effective $\mathrm{Cd}$ elimination as well as Cd biliary excretion observed in this species during the depuration period (Le Croizier et al., 2018). In mammals, Cd bound to glutathione (GSH) was shown to be excreted from hepatocytes to bile while Cd bound to metallothionein (MT) was released into the blood before reaching other organs like kidney (Ballatori, 1991; Chan et al., 1993; Klaassen, 1978; Nordberg, 1978). In fish, MT were reported in bile (Hauser-Davis et al., 2012) and were shown to transport metal during biliary excretion in $\mathrm{Cu}$ - and Se-exposed fish (Hauser-Davis et al., 2016, 2014). As more than half of the Cd (e.g. $61.8 \pm 5.6 \%$ after the depuration period) was bound to HSP regardless of condition in the sea bass (Table 1), this may suggest that $\mathrm{Cd}$ complexed to components of the HSP fraction (i.e. MTLP or GSH) was excreted directly from cytoplasm to bile or blood without passing through another cellular compound (Figure 2). 
This elimination of Cd-saturated MT may lead to a new pool of free MT, which would be available for binding other metals. In accordance with the well-identified large Zn-binding capacities of MT and the competition between Cd and Zn (Maret, 2011; Moulis, 2010b), MT turnover during exocytosis of Cd-MT complexes may have enhanced Zn binding to newlysynthesized MT, as suggested by the significant increasing proportion of $\mathrm{Zn}$ (from $21.1 \pm$ $1.9 \%$ to $27.7 \pm 2.1 \%$ ) in the HSP fraction at the end of the depuration period (Table 1 ).

Finally, it should be noted that more disturbances in metal homeostasis were observed in the sole liver following $\mathrm{Cd}$ exposure (i.e. changes in $\mathrm{Fe}, \mathrm{Mg}, \mathrm{Mn}$ and $\mathrm{Zn}$ partitioning; Table 1), indicating a greater sensitivity to $\mathrm{Cd}$ toxicity by interference with essential elements in this species than in sea bass, which only showed a modification in the Zn distribution.

\section{Links between subcellular Cd handling and Cd toxicity in the two studied species}

While more than half of the $\mathrm{Cd}(61.8 \pm 5.6 \%)$ wasbound to HSP in the sea bass after the depuration period, $\mathrm{Cd}$ partitioning in sole showed a significantly greater $\mathrm{Cd}$ pool in the sensitive fractions $(74.3 \pm 6.2 \%)$ compared with the detoxifying fractions $(13.3 \pm 4.0 \%)$. The different storage strategies imply that different supposed paths for Cd exocytosis, discussed above (i.e. direct transport of MT-bound Cd to the membrane in sea bass versus passing of MRG-bound Cd through ER and GA before excretion by vesicles in sole), may thus be responsible for a greater sensitivity of sole to $\mathrm{Cd}$ toxicity (Figure 2; Figure 3).

When present, the storage lipid fraction accounted for a non-negligible part of the internalized $\mathrm{Cd}$ in liver (44.1 $\pm 9.8 \%$ in control sole and $24.9 \pm 0.5 \%$ in control sea bass after the depuration period) (see Supporting Information), highlighting the need to consider this novel fraction in studies on metal subcellular partitioning. $\mathrm{Cd}$ is known to stimulate the lipid peroxidation process, defined as oxidative deterioration of polyunsaturated fatty acids and 
resulting in alteration of cell membranes (Roméo et al., 2000; Viarengo et al., 1989). Cd binding to this fraction may thus cause oxidation of neutral lipids, preventing their use in membrane structure. Cd was also shown to reduce lipid storage efficiency, increasing utilisation of triglycerides, which finally led to a lower growth in terms of body weight in exposed fish (Pierron et al., 2007). Although no growth impairment was observed according to length measurement or HSI calculation, a significant weight decrease was found in $\mathrm{Cd}$ exposed sole compared with controls (38.8 $\pm 5.6 \mathrm{~g}$ vs. $46.0 \pm 7.2 \mathrm{~g}$, respectively) (Figure 5; Table S2). Moreover, no storage lipid fraction was found in the livers of $\mathrm{Cd}$ exposed soles (see Supporting Information). In addition to the disturbances in essential metal homeostasis, the greater sensitivity of the sole to $\mathrm{Cd}$ toxicity was thus revealed by an alteration of the whole-body condition due to fat consumption.

\section{Essential metal protection against Cd toxicity in the two studied species}

One of the main mechanisms for Cd cellular toxicity is the induction of oxidative stress by production of oxygen free radicals (Almeida et al., 2002; Roméo et al., 2000). On the other hand, some elements are essential for the activity of antioxidant enzymes like glutathione peroxidases (GPX), catalases (CAT) and superoxide dismutases (SOD), which contain $\mathrm{Se}, \mathrm{Fe}$ and $\mathrm{Mn}-\mathrm{Cu}-\mathrm{Zn}$ as cofactors, respectively (Vural et al., 2010). These enzymes are highly involved in preventing oxidative stress in fish and a relative higher level of essential metals may thus provide a better protection against $\mathrm{Cd}$ toxicity through higher activity of antioxidant enzymes (Basha and Rani, 2003; Janz, 2011; Martínez-Álvarez et al., 2005). For instance, oxidative stress caused by $\mathrm{Cd}$ was reduced by Se treatment in the liver of the rainbow trout (Talas et al., 2008), while a Zn-deficiency was responsible for oxidative stress in the same species (Hidalgo et al., 2002). Besides the well documented role of Se in the 
301

302

303

304

305

306

307

308

309

310

311

312

313

314

315

316

317

318

319

320

321

322

323

detoxification of mercury $(\mathrm{Hg})$ through formation of $\mathrm{Hg}$-Se complexes (Khan and Wang, 2009; Pelletier, 1986), it has been suggested that Se could also complex with Cd and subsequently bind to selenoprotein $\mathrm{P}$, thus reducing $\mathrm{Cd}$ availability and toxicity (Sasakura and T. Suzuki, 1998; Siscar et al., 2014). The resistance of a species to Cd toxicity may thus depend partially on the level of elements enhancing antioxidant response or able to complex Cd. The two fish species investigated in our study presented some differences in hepatic concentrations of such elements (Figure 3). While sea bass liver contained significantly more Fe $\left(27.8 \pm 6.6 \mu \mathrm{g} \cdot \mathrm{g}^{-1}\right.$ in sea bass vs. $8.3 \pm 2.5 \mu \mathrm{g} \cdot \mathrm{g}^{-1}$ in sole), sole showed higher concentrations of $\mathrm{Cu}, \mathrm{Mn}$ and Se $\left(e . g .66 \pm 35.6 \mu \mathrm{g} \cdot \mathrm{g}^{-1}\right.$ of $\mathrm{Cu}$ in sole vs. $9.9 \pm 2.0 \mu \mathrm{g} \cdot \mathrm{g}^{-1}$ of $\mathrm{Cu}$ in sea bass) (see Supporting Information and Figure 3). Regarding essential metal concentrations, the two species thus seem to possess contrasting defense capabilities, involving different antioxidant enzymes.

Despite significantly higher levels of $C d$ in two sensitive fractions in sea bass $(12 \pm 4.2 \%$ in mitochondria and $6.3 \pm 1.8 \%$ in cytosolic HDP) compared with sole $(3.8 \pm 1.2 \%$ in mitochondria and $0.5 \pm 0.0 \%$ in HDP) after Cd exposure, sea bass also contained more antioxidant metals ( $\mathrm{Cu}$, Se and $\mathrm{Zn}$ ) in these fractions (e.g. $12.3 \pm 3.7 \%$ vs. $3.2 \pm 0.2 \%$ of $\mathrm{Cu}$ in mitochondria for sea bass and sole, respectively) (Figure 1). Similarly, after depuration, large proportions of $\mathrm{Cu}, \mathrm{Mg}, \mathrm{Mn}$, Se and $\mathrm{Zn}$ were observed alongside the significantly higher $\mathrm{Cd}$ proportions in two sensitive fractions $(51.5 \pm 4.8 \%$ in organelles and $18.8 \pm 1.1 \%$ in cytosolic HDP) in sole compared with sea bass (15.4 $\pm 4.7 \%$ in organelles and $9.0 \pm 1.4 \%$ in HDP). As the three types of antioxidant enzyme (GPx, CAT and SOD) are all found in cytosol, mitochondria and organelles (Bai et al., 1999; Martínez-Álvarez et al., 2005; Orbea et al., 2000), the fact that essential metals followed Cd distribution in sensitive fractions may 
reflect their mobilization to activate antioxidant defences and a role in preventing $\mathrm{Cd}$ damage to cellular components.

\section{Link between Cd partitioning and hepatic excretion}

In a previous study, higher MT concentration combined with higher Cd biliary excretion and relocation to muscle were found in sea bass than in sole, suggesting that MT level would enhance Cd excretion from the liver (Le Croizier et al., 2018). These differences between the two species were attributed to metabolism and/or phylogenetic divergences. Indeed, seabass is characterized by a higher metabolism, which can increase the need for essential metals and thus the need for binding sites such as MT. Moreover, the two species exhibited significant variation in the MT sequence, potentially leading to difference in terms of function. Finally, these evolutionary divergences have probably been accentuated by contrasting ecological niches (i.e., demersal for sea bass versus benthic for sole), leading sea bass to be more adapted to manage $\mathrm{Cd}$ sequestration in MT compared to sole. Even if $\mathrm{Cd}$ was also excreted from sole hepatocytes, Cd elimination seemed higher in sea bass (not significant) since around $60 \%$ of the $\mathrm{Cd}$ in liver was eliminated in this species after two months of depuration versus around $40 \%$ in sole (Le Croizier et al., 2018) (Figure S1, Supporting Information). Regarding subcellular partitioning, two main mechanisms were likely to give sea bass a greater Cd elimination from hepatocytes.

First, the large proportion of $\mathrm{Cd}$ bound to HSP may facilitate biliary excretion via transport of Cd/GSH complexes through a specific transporter of GSH present in the canalicular membrane (Zalups and Ahmad, 2003), or via transport of Cd/MT complexes as suggested by recent observations of MT in bile of metal-exposed fish (Hauser-Davis et al., 2016, 2014, 2012) (Figure 2). 
Second, transport of $\mathrm{Cd} / \mathrm{MT}$ through plasma membrane in the sea bass may be faster than

348

349

350

351

352

vesicular exocytosis occurring in sole. Although MT release from various organs to the blood has been proven, the mechanisms for epithelial transport of MT (Chan et al., 1993; Moltedo et al., 2000) and Cd/MT complex transport (Moulis et al., 2014; Sabolić et al., 2010; Zalups and Ahmad, 2003) are unknown. FIHUREby the classical vesicular secretory pathway while transport across membranes must occur directly from the cytoplasm to the exterior of the cell through ATP-binding cassette transporters (ABC transporters) (De Lisle et al., 1996) (Figure 2). Conversely, vesicular exocytosis of MRG-derived $\mathrm{Cd}$ in sole must involve successive steps, including fusion of vesicle and plasma membranes, which induces a slower removal of Cd compared to direct excretion in sea bass.

\section{CONCLUSIONS}

The present study identified two different Cd elimination pathways in European sea bass Dicentrarchus labrax and Senegalese sole Solea senegalensis, exposed for two months to an environmentally realistic dietary $\mathrm{Cd}$ dose. The species-specific strategies imply differences in metal transport and sensitivity to $\mathrm{Cd}$ toxicity. In sea bass, $\mathrm{Cd}$ was mainly bound to metallothionein-like proteins and would be excreted through bile or released into the blood. In sole, granules-bound Cd would be sequestered by organelles and may thus be responsible for a greater sensitivity of sole to Cd toxicity, revealed by an alteration of the whole-body condition due to fat consumption. These results moreover bring significant novelties demonstrating that MT and MRG are involved in metal elimination from liver, through either biliary excretion or transport to other tissues, as these cell components were so far considered as long term metal storage fractions (Vijver et al., 2004; Wallace et al., 2003; Wang and Rainbow, 2010). Future studies should therefore focus on the membrane 
pathways on metal retention and sensitivity of marine fish species to toxic elements such as

Cd.

\section{Acknowledgements}

The authors thank greatly Jean Raffray for the dissection of the fish. This study benefited of

the technical support of the Centre of Documentation, Research and Experimentation on

Accidental Water Pollution (CEDRE). This work was financially supported by the French

National Research Agency project ANR-11-CEPL-0005 EPURE.

\section{REFERENCES}

Ackerman, P.A., Morgan, J.D., Iwama, G.K., 2005. Les anésthésiques.

Afandi, I., Talba, S., Benhra, A., Benbrahim, S., Chfiri, R., Labonne, M., Masski, H., Laë, R., Morais, L.T.D., Bekkali, M., Bouthir, F.Z., 2018. Trace metal distribution in pelagic fish species from the north-west African coast (Morocco). Int Aquat Res 10, 191-205. https://doi.org/10.1007/s40071-018-0192-7

Almeida, J.A., Diniz, Y.S., Marques, S.F.G., Faine, L.A., Ribas, B.O., Burneiko, R.C., Novelli, E.L.B., 2002. The use of the oxidative stress responses as biomarkers in Nile tilapia (Oreochromis niloticus) exposed to in vivo cadmium contamination. Environment International 27, 673-679. https://doi.org/10.1016/S01604120(01)00127-1

Auger, P.A., Machu, E., Gorgues, T., Grima, N., Waeles, M., 2015. Comparative study of potential transfer of natural and anthropogenic cadmium to plankton communities in the North-West African upwelling. Science of The Total Environment 505, 870-888. https://doi.org/10.1016/j.scitotenv.2014.10.045

Bai, J., Rodriguez, A.M., Melendez, J.A., Cederbaum, A.I., 1999. Overexpression of Catalase in Cytosolic or Mitochondrial Compartment Protects HepG2 Cells against Oxidative Injury. J. Biol. Chem. 274, 26217-26224. https://doi.org/10.1074/jbc.274.37.26217

Baldisserotto, B., Chowdhury, M.J., Wood, C.M., 2005. Effects of dietary calcium and cadmium on cadmium accumulation, calcium and cadmium uptake from the water, and their interactions in juvenile rainbow trout. Aquatic Toxicology, Mechanisms in Metal Toxicology 72, 99-117. https://doi.org/10.1016/j.aquatox.2004.11.019

Ballatori, N., 1991. Mechanisms of metal transport across liver cell plasma membranes. Drug Metab. Rev. 23, 83-132. https://doi.org/10.3109/03602539109029757

Bartlett, M.S., 1937. Properties of sufficiency and statistical tests. Proc. R. Soc. Lond. A 160, 268-282. https://doi.org/10.1098/rspa.1937.0109 
Basha, P.S., Rani, A.U., 2003. Cadmium-induced antioxidant defense mechanism in freshwater teleost Oreochromis mossambicus (Tilapia). Ecotoxicology and Environmental Safety 56, 218-221. https://doi.org/10.1016/S0147-6513(03)00028-9

Bodin, N., N'Gom-Kâ, R., Kâ, S., Thiaw, O.T., Tito de Morais, L., Le Loc'h, F., RozuelChartier, E., Auger, D., Chiffoleau, J.-F., 2013. Assessment of trace metal contamination in mangrove ecosystems from Senegal, West Africa. Chemosphere 90, 150-157. https://doi.org/10.1016/j.chemosphere.2012.06.019

Borrell, A., Tornero, V., Bhattacharjee, D., Aguilar, A., 2016. Trace element accumulation and trophic relationships in aquatic organisms of the Sundarbans mangrove ecosystem (Bangladesh). Science of The Total Environment 545-546, 414-423. https://doi.org/10.1016/j.scitotenv.2015.12.046

Campbell, P.G.C., Kraemer, L.D., Giguère, A., Hare, L., Hontela, A., 2008. Subcellular Distribution of Cadmium and Nickel in Chronically Exposed Wild Fish: Inferences Regarding Metal Detoxification Strategies and Implications for Setting Water Quality Guidelines for Dissolved Metals. Human and Ecological Risk Assessment: An International Journal 14, 290-316. https://doi.org/10.1080/10807030801935009

Chan, H.M., Zhu, L.F., Zhong, R., Grant, D., Goyer, R.A., Cherian, M.G., 1993. Nephrotoxicity in Rats Following Liver Transplantation from Cadmium-Exposed Rats. Toxicology and Applied Pharmacology 123, 89-96. https://doi.org/10.1006/taap.1993.1225

Cheggour, M., Langston, W.J., Chafik, A., Texier, H., Idrissi, H., Boumezzough, A., 1999. Phosphate industry discharges and their impact on metal contamination and intertidal macrobenthos: Jorf Lasfar and Safi coastlines (Morocco). Toxicological \& Environmental Chemistry 70, 159-179.

Conover, W.J., Iman, R.L., 1979. Multiple-comparisons procedures. Informal report (No. LA7677-MS). Los Alamos Scientific Lab., NM (USA).

Dallinger, R., Egg, M., Köck, G., Hofer, R., 1997. The role of metallothionein in cadmium accumulation of Arctic char (Salvelinus alpinus) from high alpine lakes. Aquatic Toxicology 38, 47-66. https://doi.org/10.1016/S0166-445X(96)00840-5

Danion, M., Le Floch, S., Kanan, R., Lamour, F., Quentel, C., 2011. Effects of in vivo chronic hydrocarbons pollution on sanitary status and immune system in sea bass (Dicentrarchus labrax L.). Aquatic Toxicology 105, 300-311. https://doi.org/10.1016/j.aquatox.2011.06.022

De Lisle, R.C., Sarras, M.P., Hidalgo, J., Andrews, G.K., 1996. Metallothionein is a component of exocrine pancreas secretion: implications for zinc homeostasis. Am. J. Physiol. 271, C1103-1110.

Diop, M., Howsam, M., Diop, C., Cazier, F., Goossens, J.F., Diouf, A., Amara, R., 2016. Spatial and seasonal variations of trace elements concentrations in liver and muscle of round Sardinelle (Sardinella aurita) and Senegalese sole (Solea senegalensis) along the Senegalese coast. Chemosphere 144, 758-766. https://doi.org/10.1016/j.chemosphere.2015.08.085

Eyckmans, M., Blust, R., De Boeck, G., 2012. Subcellular differences in handling Cu excess in three freshwater fish species contributes greatly to their differences in sensitivity to $\mathrm{Cu}$. Aquatic Toxicology 118-119, 97-107. https://doi.org/10.1016/j.aquatox.2012.03.019

Fan, W., Xu, Z., Wang, W.-X., 2015. Contrasting metal detoxification in polychaetes, bivalves and fish from a contaminated bay. Aquatic Toxicology 159, 62-68. https://doi.org/10.1016/j.aquatox.2014.11.024

Gaudry, A., Zeroual, S., Gaie-Levrel, F., Moskura, M., Boujrhal, F.Z., El Moursli, R.C., Guessous, A., Mouradi, A., Givernaud, T., Delmas, R., 2007. Heavy Metals Pollution 
of the Atlantic Marine Environment by the Moroccan Phosphate Industry, as Observed through their Bioaccumulation in Ulva Lactuca. Water, Air, \& Soil Pollution 178, $267-285$.

George, S.G., Pirie, B.J.S., Coombs, T.L., 1980. Isolation and elemental analysis of metal-rich granules from the kidney of the scallop, Pecten maximus (L.). Journal of Experimental Marine Biology and Ecology 42, 143-156. https://doi.org/10.1016/00220981(80)90172-0

Giguère, A., Campbell, P.G.C., Hare, L., Couture, P., 2006. Sub-cellular partitioning of cadmium, copper, nickel and zinc in indigenous yellow perch (Perca flavescens) sampled along a polymetallic gradient. Aquatic Toxicology 77, 178-189. https://doi.org/10.1016/j.aquatox.2005.12.001

Glynn, A.W., 1991. Cadmium and Zinc Kinetics in Fish: Studies on Water-Borne 109Cd and 65Zn Turnover and Intracellular Distribution in Minnows, Phoxinus phoxinus. Pharmacology \& Toxicology 68, 485-491. https://doi.org/10.1111/j.16000773.1991.tb01274.x

Görlach, A., Klappa, P., Kietzmann, D.T., 2006. The Endoplasmic Reticulum: Folding, Calcium Homeostasis, Signaling, and Redox Control. Antioxidants \& Redox Signaling 8, 1391-1418. https://doi.org/10.1089/ars.2006.8.1391

Goutte, A., Cherel, Y., Churlaud, C., Ponthus, J.-P., Massé, G., Bustamante, P., 2015. Trace elements in Antarctic fish species and the influence of foraging habitats and dietary habits on mercury levels. Science of The Total Environment 538, 743-749. https://doi.org/10.1016/j.scitotenv.2015.08.103

Harrison, S.E., Curtis, P.J., 1992. Comparative accumulation efficiency of 109cadmium from natural food (Hyalella azteca) and artificial diet by rainbow trout (Oncorhynchus mykiss). Bull. Environ. Contam. Toxicol. 49, 757-764. https://doi.org/10.1007/BF00200791

Hauser-Davis, R.A., Bastos, F.F., Tuton, B., Chávez Rocha, R., Pierre, T.S., Ziolli, R.L., Arruda, M.A.Z., 2014. Bile and liver metallothionein behavior in copper-exposed fish. Journal of Trace Elements in Medicine and Biology 28, 70-74. https://doi.org/10.1016/j.jtemb.2013.09.003

Hauser-Davis, R.A., Gonçalves, R.A., Ziolli, R.L., Campos, R.C. de, 2012. A novel report of metallothioneins in fish bile: SDS-PAGE analysis, spectrophotometry quantification and metal speciation characterization by liquid chromatography coupled to ICP-MS. Aquatic Toxicology 116-117, 54-60. https://doi.org/10.1016/j.aquatox.2012.03.003

Hauser-Davis, R.A., Silva, J.A.N., Rocha, R.C.C., Saint'Pierre, T., Ziolli, R.L., Arruda, M.A.Z., 2016. Acute selenium selenite exposure effects on oxidative stress biomarkers and essential metals and trace-elements in the model organism zebrafish (Danio rerio). Journal of Trace Elements in Medicine and Biology 33, 68-72. https://doi.org/10.1016/j.jtemb.2015.09.001

Hidalgo, M.C., Expósito, A., Palma, J.M., Higuera, M. de la, 2002. Oxidative stress generated by dietary Zn-deficiency: studies in rainbow trout (Oncorhynchus mykiss). The International Journal of Biochemistry \& Cell Biology 34, 183-193. https://doi.org/10.1016/S1357-2725(01)00105-4

Janz, D.M., 2011. 7 - Selenium, in: Chris M. Wood, A.P.F. and C.J.B. (Ed.), Fish Physiology, Homeostasis and Toxicology of Essential Metals. Academic Press, pp. 327-374. https://doi.org/10.1016/S1546-5098(11)31007-2

Kamunde, C., MacPhail, R., 2011a. Subcellular interactions of dietary cadmium, copper and zinc in rainbow trout (Oncorhynchus mykiss). Aquatic Toxicology 105, 518-527. https://doi.org/10.1016/j.aquatox.2011.08.005 
Kamunde, C., MacPhail, R., 2011b. Metal-metal interactions of dietary cadmium, copper and zinc in rainbow trout, Oncorhynchus mykiss. Ecotoxicol. Environ. Saf. 74, 658-667. https://doi.org/10.1016/j.ecoenv.2010.10.016

Khan, M.A.K., Wang, F., 2009. Mercury-selenium compounds and their toxicological significance: Toward a molecular understanding of the mercury-selenium antagonism. Environmental Toxicology and Chemistry 28, 1567-1577. https://doi.org/10.1897/08375.1

Klaassen, C.D., 1978. Effect of metallothionein on hepatic disposition of metals. Am. J. Physiol. 234, E47-53.

Kwong, R.W.M., Andrés, J.A., Niyogi, S., 2010. Molecular evidence and physiological characterization of iron absorption in isolated enterocytes of rainbow trout (Oncorhynchus mykiss): Implications for dietary cadmium and lead absorption. Aquatic Toxicology 99, 343-350. https://doi.org/10.1016/j.aquatox.2010.05.012

Lapointe, D., Gentès, S., Ponton, D.E., Hare, L., Couture, P., 2009a. Influence of Prey Type on Nickel and Thallium Assimilation, Subcellular Distribution and Effects in Juvenile Fathead Minnows (Pimephales promelas). Environ. Sci. Technol. 43, 8665-8670. https://doi.org/10.1021/es901929m

Lapointe, D., Gentès, S., Ponton, D.E., Hare, L., Couture, P., 2009b. Influence of Prey Type on Nickel and Thallium Assimilation, Subcellular Distribution and Effects in Juvenile Fathead Minnows (Pimephales promelas). Environ. Sci. Technol. 43, 8665-8670. https://doi.org/10.1021/es901929m

Le Croizier, G., Lacroix, C., Artigaud, S., Le Floch, S., Raffray, J., Penicaud, V., Coquillé, V., Autier, J., Rouget, M.-L., Le Bayon, N., Laë, R., Tito De Morais, L., 2018. Significance of metallothioneins in differential cadmium accumulation kinetics between two marine fish species. Environmental Pollution 236, 462-476. https://doi.org/10.1016/j.envpol.2018.01.002

Le Croizier, G., Schaal, G., Gallon, R., Fall, M., Le Grand, F., Munaron, J.-M., Rouget, M.L., Machu, E., Le Loc'h, F., Laë, R., De Morais, L.T., 2016. Trophic ecology influence on metal bioaccumulation in marine fish: Inference from stable isotope and fatty acid analyses. Science of The Total Environment 573, 83-95. https://doi.org/10.1016/j.scitotenv.2016.08.035

Leonard, E.M., Banerjee, U., D’Silva, J.J., Wood, C.M., 2014. Chronic nickel bioaccumulation and sub-cellular fractionation in two freshwater teleosts, the round goby and the rainbow trout, exposed simultaneously to waterborne and dietborne nickel. Aquatic Toxicology 154, 141-153. https://doi.org/10.1016/j.aquatox.2014.04.028

Maanan, M., 2008. Heavy metal concentrations in marine molluscs from the Moroccan coastal region. Environmental Pollution 153, 176-183. https://doi.org/10.1016/j.envpol.2007.07.024

Maret, W., 2011. Metals on the move: zinc ions in cellular regulation and in the coordination dynamics of zinc proteins. Biometals 24, 411-418. https://doi.org/10.1007/s10534010-9406-1

Martelli, A., Rousselet, E., Dycke, C., Bouron, A., Moulis, J.-M., 2006. Cadmium toxicity in animal cells by interference with essential metals. Biochimie, Facets of Environmental Nuclear Toxicology 88, 1807-1814. https://doi.org/10.1016/j.biochi.2006.05.013

Martínez-Álvarez, R.M., Morales, A.E., Sanz, A., 2005. Antioxidant Defenses in Fish: Biotic and Abiotic Factors. Rev Fish Biol Fisheries 15, 75-88. https://doi.org/10.1007/s11160-005-7846-4 
McGeer, J.C., Niyogi, S., Scott Smith, D., 2011. 3 - Cadmium, in: Chris M. Wood, A.P.F. and C.J.B. (Ed.), Fish Physiology, Homeostasis and Toxicology of Non-Essential Metals. Academic Press, pp. 125-184. https://doi.org/10.1016/S1546-5098(11)31025-4

Metian, M., Warnau, M., Chouvelon, T., Pedraza, F., Rodriguez y Baena, A.M., Bustamante, P., 2013. Trace element bioaccumulation in reef fish from New Caledonia: Influence of trophic groups and risk assessment for consumers. Marine Environmental Research 87-88, 26-36. https://doi.org/10.1016/j.marenvres.2013.03.001

Moltedo, O., Verde, C., Capasso, A., Parisi, E., Remondelli, P., Bonatti, S., AlvarezHernandez, X., Glass, J., Alvino, C.G., Leone, A., 2000. Zinc Transport and Metallothionein Secretion in the Intestinal Human Cell Line Caco-2. J. Biol. Chem. 275, 31819-31825. https://doi.org/10.1074/jbc.M002907200

Moulis, J.-M., 2010a. Cellular mechanisms of cadmium toxicity related to the homeostasis of essential metals. Biometals 23, 877-896. https://doi.org/10.1007/s10534-010-9336-y

Moulis, J.-M., 2010b. Cellular mechanisms of cadmium toxicity related to the homeostasis of essential metals. Biometals 23, 877-896. https://doi.org/10.1007/s10534-010-9336-y

Moulis, J.-M., Bourguignon, J., Catty, P., 2014. CHAPTER 23:Cadmium, in: Binding, Transport and Storage of Metal Ions in Biological Cells. pp. 695-746. https://doi.org/10.1039/9781849739979-00695

Ng, T.Y.-T., Klinck, J.S., Wood, C.M., 2009. Does dietary Ca protect against toxicity of a low dietborne Cd exposure to the rainbow trout? Aquatic Toxicology 91, 75-86. https://doi.org/10.1016/j.aquatox.2008.10.008

Nordberg, M., 1978. Studies on metallothionein and cadmium. Environmental Research 15, 381-404. https://doi.org/10.1016/0013-9351(78)90120-2

Orbea, A., Fahimi, H.D., Cajaraville, M.P., 2000. Immunolocalization of four antioxidant enzymes in digestive glands of mollusks and crustaceans and fish liver. Histochem Cell Biol 114, 393-404. https://doi.org/10.1007/s004180000207

Pelletier, E., 1986. Mercury-selenium interactions in aquatic organisms: A review. Marine Environmental Research 18, 111-132. https://doi.org/10.1016/0141-1136(86)90003-6

Pierron, F., Baudrimont, M., Bossy, A., Bourdineaud, J.-P., Brèthes, D., Elie, P., Massabuau, J.-C., 2007. Impairment of lipid storage by cadmium in the European eel (Anguilla anguilla). Aquatic Toxicology 81, 304-311. https://doi.org/10.1016/j.aquatox.2006.12.014

Pouil, S., Bustamante, P., Warnau, M., Metian, M., 2018. Overview of trace element trophic transfer in fish through the concept of assimilation efficiency. Marine Ecology Progress Series 588, 243-254. https://doi.org/10.3354/meps 12452

Pouil, S., Warnau, M., Oberhänsli, F., Teyssié, J.-L., Metian, M., 2015. Trophic transfer of $110 \mathrm{mAg}$ in the turbot Scophthalmus maximus through natural prey and compounded feed. Journal of Environmental Radioactivity 150, 189-194. https://doi.org/10.1016/j.jenvrad.2015.08.016

Roméo, M., Bennani, N., Gnassia-Barelli, M., Lafaurie, M., Girard, J.P., 2000. Cadmium and copper display different responses towards oxidative stress in the kidney of the sea bass Dicentrarchus labrax. Aquatic Toxicology 48, 185-194. https://doi.org/10.1016/S0166-445X(99)00039-9

Rosabal, M., Pierron, F., Couture, P., Baudrimont, M., Hare, L., Campbell, P.G.C., 2015. Subcellular partitioning of non-essential trace metals ( $\mathrm{Ag}, \mathrm{As}, \mathrm{Cd}, \mathrm{Ni}, \mathrm{Pb}$, and $\mathrm{Tl}$ ) in livers of American (Anguilla rostrata) and European (Anguilla anguilla) yellow eels. Aquatic Toxicology 160, 128-141. https://doi.org/10.1016/j.aquatox.2015.01.011

Sabolić, I., Breljak, D., Škarica, M., Herak-Kramberger, C.M., 2010. Role of metallothionein in cadmium traffic and toxicity in kidneys and other mammalian organs. Biometals 23, 897-926. https://doi.org/10.1007/s10534-010-9351-z 
605

606

607

608

609

610

611

612

613

614

615

616

617

618

619

620

621

622

623

624

625

626

627

628

629

630

631

632

633

634

635

636

637

638

639

640

641

642

643

644

645

646

647

648

649

650

651

652

653

Salas-Leiton, E., Anguis, V., Martín-Antonio, B., Crespo, D., Planas, J.V., Infante, C., Cañavate, J.P., Manchado, M., 2010. Effects of stocking density and feed ration on growth and gene expression in the Senegalese sole (Solea senegalensis): Potential effects on the immune response. Fish \& Shellfish Immunology 28, 296-302. https://doi.org/10.1016/j.fsi.2009.11.006

Sasakura, C., T. Suzuki, K., 1998. Biological interaction between transition metals (Ag, Cd and $\mathrm{Hg}$ ), selenide/sulfide and selenoprotein P. Journal of Inorganic Biochemistry 71, 159-162. https://doi.org/10.1016/S0162-0134(98)10048-X

Shapiro, S.S., Wilk, M.B., 1965. An Analysis of Variance Test for Normality (Complete Samples). Biometrika 52, 591-611. https://doi.org/10.2307/2333709

Siscar, R., Koenig, S., Torreblanca, A., Solé, M., 2014. The role of metallothionein and selenium in metal detoxification in the liver of deep-sea fish from the NW Mediterranean Sea. Science of The Total Environment 466-467, 898-905. https://doi.org/10.1016/j.scitotenv.2013.07.081

Talas, Z.S., Orun, I., Ozdemir, I., Erdogan, K., Alkan, A., Y1lmaz, I., 2008. Antioxidative role of selenium against the toxic effect of heavy metals $(\mathrm{Cd}+2, \mathrm{Cr}+3)$ on liver of rainbow trout (Oncorhynchus mykiss Walbaum 1792). Fish Physiol Biochem 34, 217-222. https://doi.org/10.1007/s10695-007-9179-9

Viarengo, A., Pertica, M., Canesi, L., Accomando, R., Mancinelli, G., Orunesu, M., 1989. Lipid peroxidation and level of antioxidant compounds (GSH, vitamin E) in the digestive glands of mussels of three different age groups exposed to anaerobic and aerobic conditions. Marine Environmental Research, Responses of Marine Organisms to Pollutants 28, 291-295. https://doi.org/10.1016/0141-1136(89)90246-8

Vijver, M.G., van Gestel, C.A.M., Lanno, R.P., van Straalen, N.M., Peijnenburg, W.J.G.M., 2004. Internal Metal Sequestration and Its Ecotoxicological Relevance: A Review. Environ. Sci. Technol. 38, 4705-4712. https://doi.org/10.1021/es040354g

Vural, H., Demirin, H., Kara, Y., Eren, I., Delibas, N., 2010. Alterations of plasma magnesium, copper, zinc, iron and selenium concentrations and some related erythrocyte antioxidant enzyme activities in patients with Alzheimer's disease. Journal of Trace Elements in Medicine and Biology 24, 169-173. https://doi.org/10.1016/j.jtemb.2010.02.002

Wallace, W.G., Lee, B., Luoma, S.N., 2003. Subcellular compartmentalization of Cd and Zn in two bivalves. I. Significance of metal-sensitive fractions (MSF) and biologically detoxified metal (BDM). Mar Ecol Prog Ser 249, 183-197. https://doi.org/10.3354/meps249183

Wang, W., Rainbow, P.S., 2006. Subcellular Partitioning and the Prediction of Cadmium Toxicity to Aquatic Organisms. Environ. Chem. 3, 395-399.

Wang, W.-X., Rainbow, P.S., 2010. Significance of metallothioneins in metal accumulation kinetics in marine animals. Comparative Biochemistry and Physiology Part C: Toxicology \& Pharmacology 152, 1-8. https://doi.org/10.1016/j.cbpc.2010.02.015

World Health Organization, 2010. Exposure to cadmium: A Major public health concern.

Zalups, R.K., Ahmad, S., 2003. Molecular handling of cadmium in transporting epithelia. Toxicology and Applied Pharmacology 186, 163-188. https://doi.org/10.1016/S0041008X(02)00021-2

Zhao, W., Liu, W., Chen, X., Zhu, Y., Zhang, Z., Yao, H., Xu, S., 2014. Four Endoplasmic Reticulum Resident Selenoproteins May Be Related to the Protection of Selenium Against Cadmium Toxicity in Chicken Lymphocytes. Biol Trace Elem Res 161, 328333. https://doi.org/10.1007/s12011-014-0135-0 


\begin{tabular}{|c|c|c|c|c|c|c|c|}
\hline \multirow[b]{3}{*}{ Species } & \multirow[b]{3}{*}{ Element } & \multicolumn{6}{|c|}{ Subcellular partitioning (\%) } \\
\hline & & \multicolumn{2}{|c|}{ Organelles } & \multicolumn{2}{|c|}{ MRG } & \multicolumn{2}{|c|}{ MTLP } \\
\hline & & Control & Exposed & Control & Exposed & Control & Exposed \\
\hline \multirow{8}{*}{ D. labrax } & $\mathrm{Cd}$ & $20.1 \pm 0.9$ & $15.4 \pm 4.7$ & $1.3 \pm 0.3$ & $1.6 \pm 0.7$ & $53.7 \pm 1.4$ & $61.8 \pm 5.6$ \\
\hline & $\mathrm{Ca}$ & $18.4 \pm 16.3$ & $12.9 \pm 3.1$ & $53.8 \pm 42.8$ & $69.3 \pm 4.1$ & $13.2 \pm 12.6$ & $9.6 \pm 3.7$ \\
\hline & $\mathrm{Cu}$ & $20.2 \pm 1.2$ & $16.5 \pm 4.8$ & $2.4 \pm 0.7$ & $2.5 \pm 1.3$ & $53.2 \pm 1.2$ & $59.8 \pm 5.9$ \\
\hline & $\mathrm{Fe}$ & $56.6 \pm 1.2$ & $60.6 \pm 12.8$ & $2.7 \pm 0.5$ & $3.1 \pm 1.5$ & $6.7 \pm 2$ & $8.3 \pm 8.3$ \\
\hline & $\mathrm{Mg}$ & $42.1 \pm 1$ & $40.3 \pm 5.4$ & $3.8 \pm 1.3$ & $4.2 \pm 1.1$ & $33.7 \pm 1.8$ & $38.8 \pm 5.7$ \\
\hline & $\mathrm{Mn}$ & $38.2 \pm 2.3$ & $37.7 \pm 4.2$ & $5.8 \pm 2.6$ & $6.1 \pm 0.7$ & $29.3 \pm 1.9$ & $33 \pm 4.5$ \\
\hline & $\mathrm{Se}$ & $31.7 \pm 1.2$ & $28.4 \pm 5.5$ & $3.1 \pm 0.3$ & $3.9 \pm 1$ & $16.6 \pm 0.1$ & $18.6 \pm 3.1$ \\
\hline & $\mathrm{Zn}$ & $28.1 \pm 0.8$ & $23.5 \pm 5$ & $1.5 \pm 0.1$ & $1.5 \pm 0.2$ & $21.1 \pm 1.9$ & $27.7 \pm 2.1$ \\
\hline \multirow{8}{*}{ S. senegalensis } & $\mathrm{Cd}$ & $37.3 \pm 5.9$ & $51.5 \pm 4.8$ & $16.4 \pm 9$ & $9.2 \pm 5.1$ & $3.9 \pm 2.4$ & $4.1 \pm 2.2$ \\
\hline & $\mathrm{Ca}$ & $28.3 \pm 10.2$ & $39.5 \pm 14.7$ & $37.7 \pm 16.9$ & $32.6 \pm 13.7$ & $17.5 \pm 2$ & $13.5 \pm 2.3$ \\
\hline & $\mathrm{Cu}$ & $36.6 \pm 6.3$ & $49.3 \pm 7.6$ & $16.9 \pm 9.6$ & $8.1 \pm 2.8$ & $3.9 \pm 3.3$ & $6.8 \pm 3.4$ \\
\hline & $\mathrm{Fe}$ & $30.1 \pm 2.4$ & $41.2 \pm 1.4$ & $16.9 \pm 3.2$ & $9.2 \pm 2.6$ & $8.9 \pm 1.3$ & $6.8 \pm 1.3$ \\
\hline & $\mathrm{Mg}$ & $36.5 \pm 6.4$ & $52.1 \pm 3.4$ & $13.6 \pm 2.7$ & $7.7 \pm 1.3$ & $28.6 \pm 2.9$ & $23 \pm 4.3$ \\
\hline & $\mathrm{Mn}$ & $36.8 \pm 3.7$ & $49.4 \pm 1.8$ & $16.8 \pm 3$ & $10.3 \pm 1.5$ & $23 \pm 4.2$ & $20.1 \pm 2.8$ \\
\hline & $\mathrm{Se}$ & $32.8 \pm 3.9$ & $43.6 \pm 6.8$ & $10.6 \pm 6.8$ & $5.8 \pm 1.4$ & $11.6 \pm 2.9$ & $12.3 \pm 1.5$ \\
\hline & $\mathrm{Zn}$ & $31.4 \pm 3.2$ & $43.3 \pm 4.1$ & $10.6 \pm 7$ & $7.4 \pm 2.2$ & $5.8 \pm 0.5$ & $4.6 \pm 0.9$ \\
\hline
\end{tabular}

\section{Table 1}

Total metal concentration (ppm dry weight, mean $\pm \mathrm{sd}$ ) and subcellular partitioning (\% of the total metal contained in each fraction, mean $\pm \mathrm{sd}$ ) of metal elements, after 60 days of cadmium depuration, in the liver of sea bass Dicentrachus labrax and Senegalese sole Solea senegalensis for both treatments (exposed and control fish, $\mathrm{n}=3$ ). Values are shown only for organelles, metal rich granules (MRG) and heat stable proteins (HSP) fractions where metal partitioning significantly differed between control and exposed fish (values in bold; ANOVA, $p<0.05$ ). 


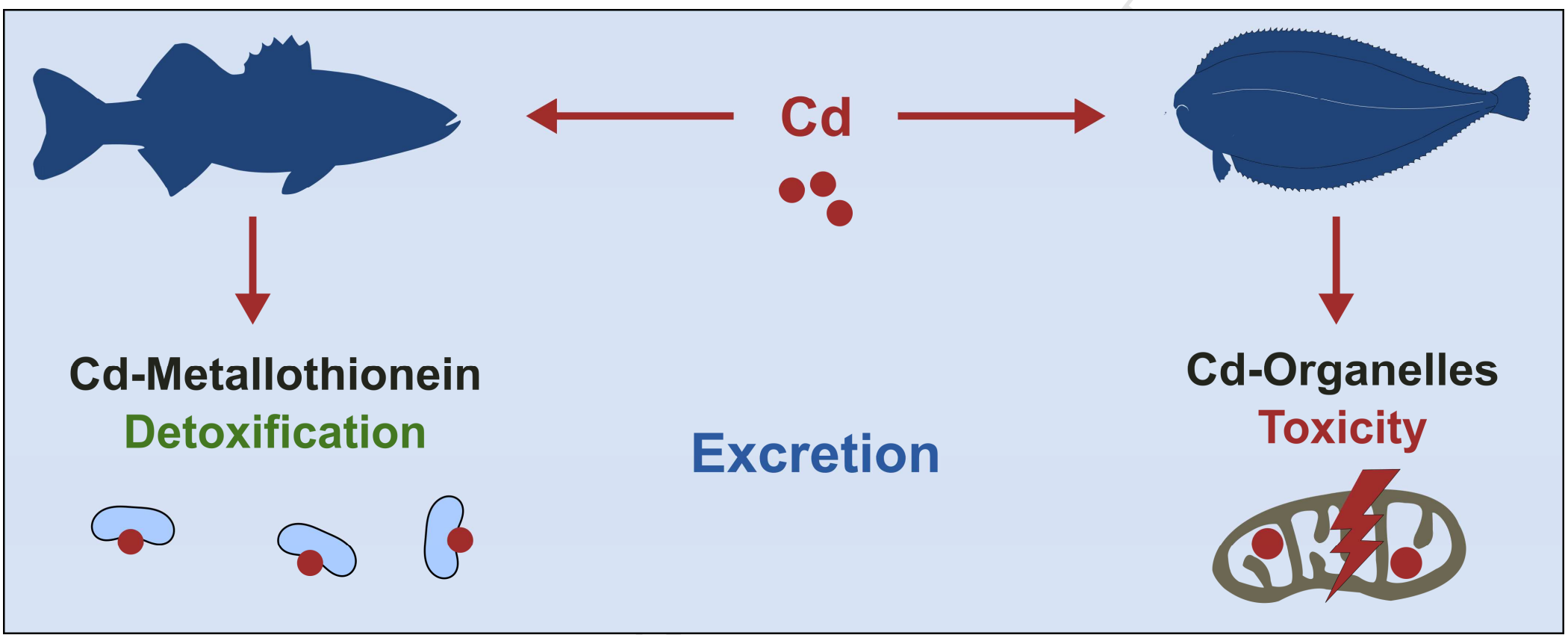



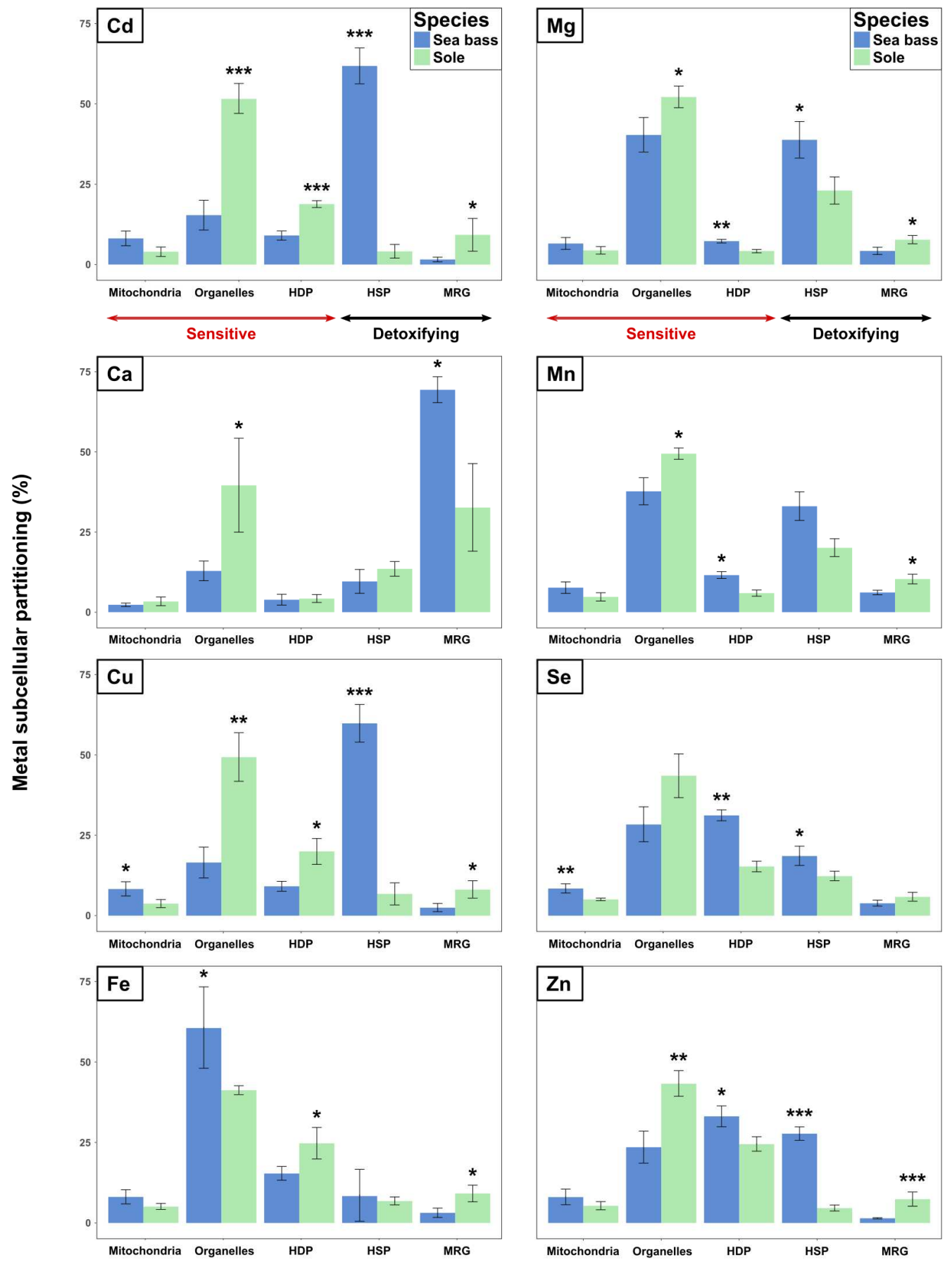

Figure 1: Subcellular partitioning of cadmium (Cd) and essential metals (\% of the total metal contained in each fraction) in the liver of sea bass Dicentrachus labrax and Senegalese sole Solea senegalensis $(n=3)$ after 60 days of depuration. The cellular debris fraction is not shown as it is neither a sensitive nor a detoxifying fraction, but was taken into account in the calculation of the partitioning (for Cd proportions in cellular debris, see Supporting Information). Significant difference between species (ANOVA) are indicated by $* p<0.05, * * p<0.01, * * * p<0.001)$. 


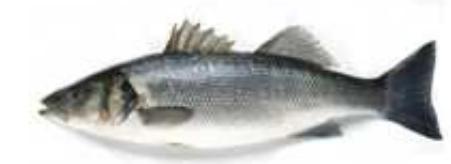

Dicentrarchus labrax
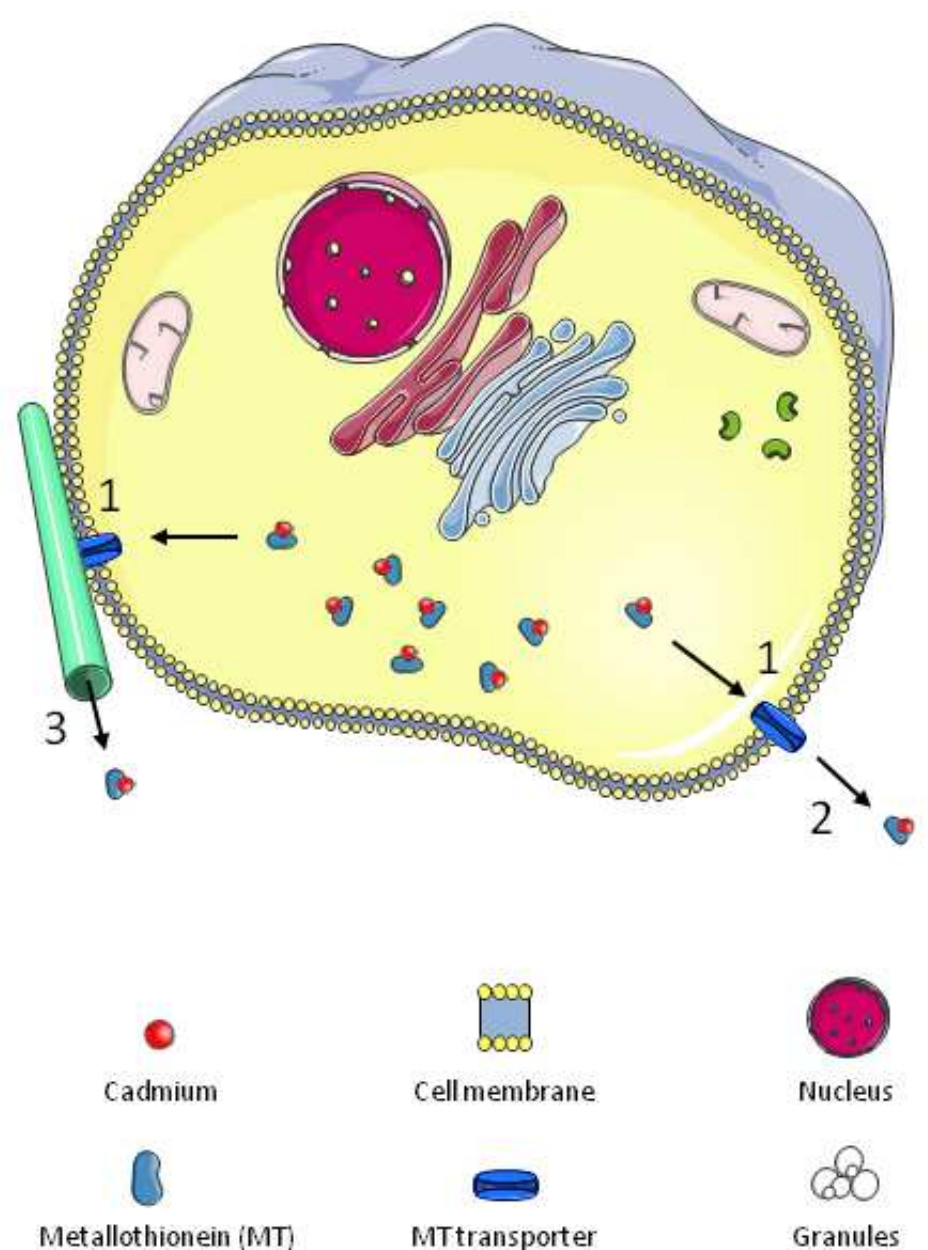

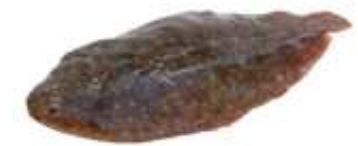

Solea senegalensis
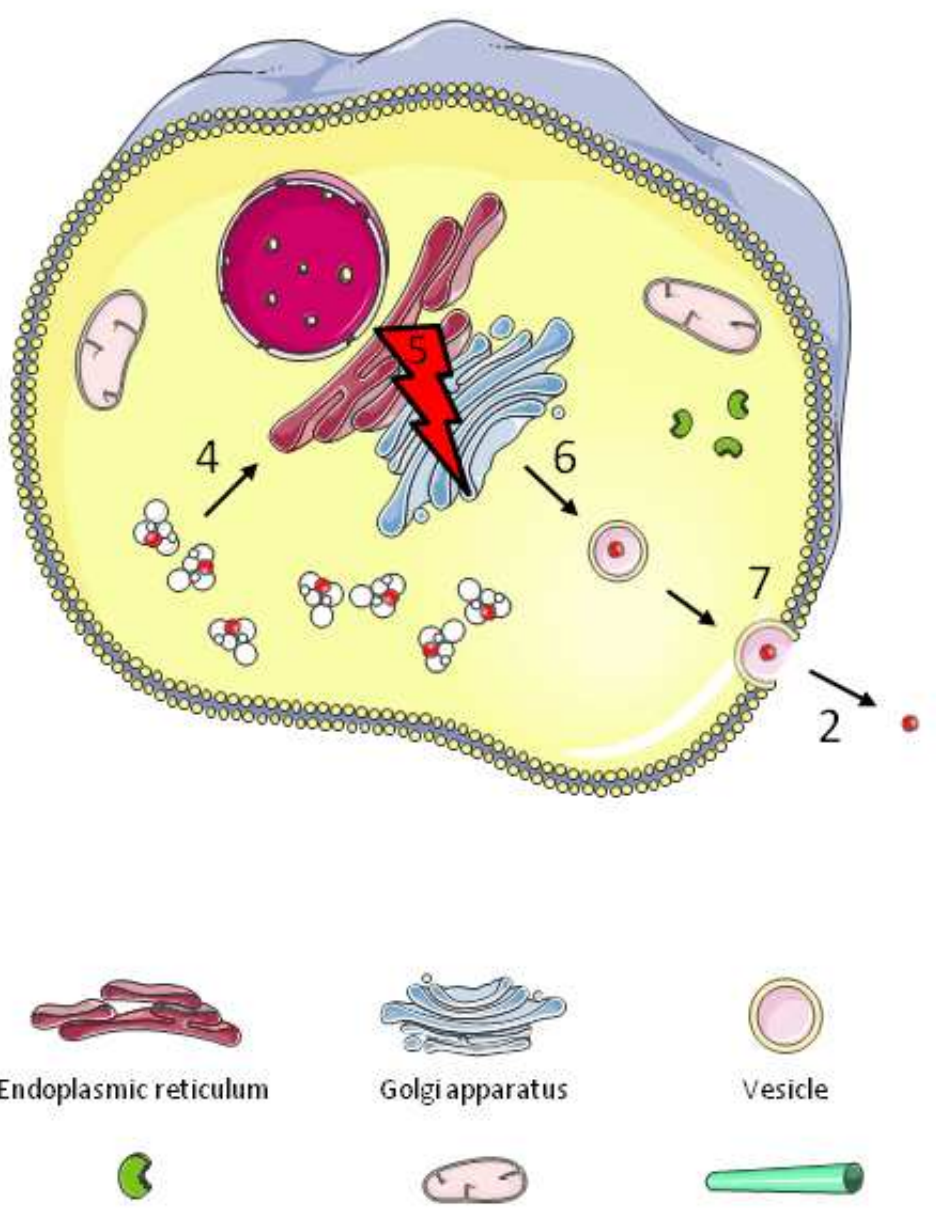

Enzyme

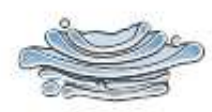

Golgi apparatus

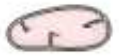

Mitochondria

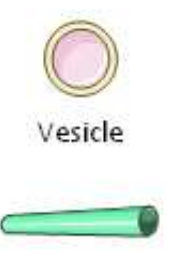

Bile canaliculus

Figure 2: Subcellular Cd dynamics in hepatocytes of sea bass Dicentrachus labrax and Senegalese sole Solea senegalensis. Only the two main mechanisms of $\mathrm{Cd}$ handling are represented: binding to metallothionein in sea bass and binding to granules in sole. 1: Excretion of Cd/MT complexes through MT transporters; 2: Release into the blood; 3: Release into bile; 4: sequestration of metal rich granules by the endoplasmic reticulum; 5: damage due to Cd toxicity; 6: vesicular transport; 7: vesicular exocytosis. 


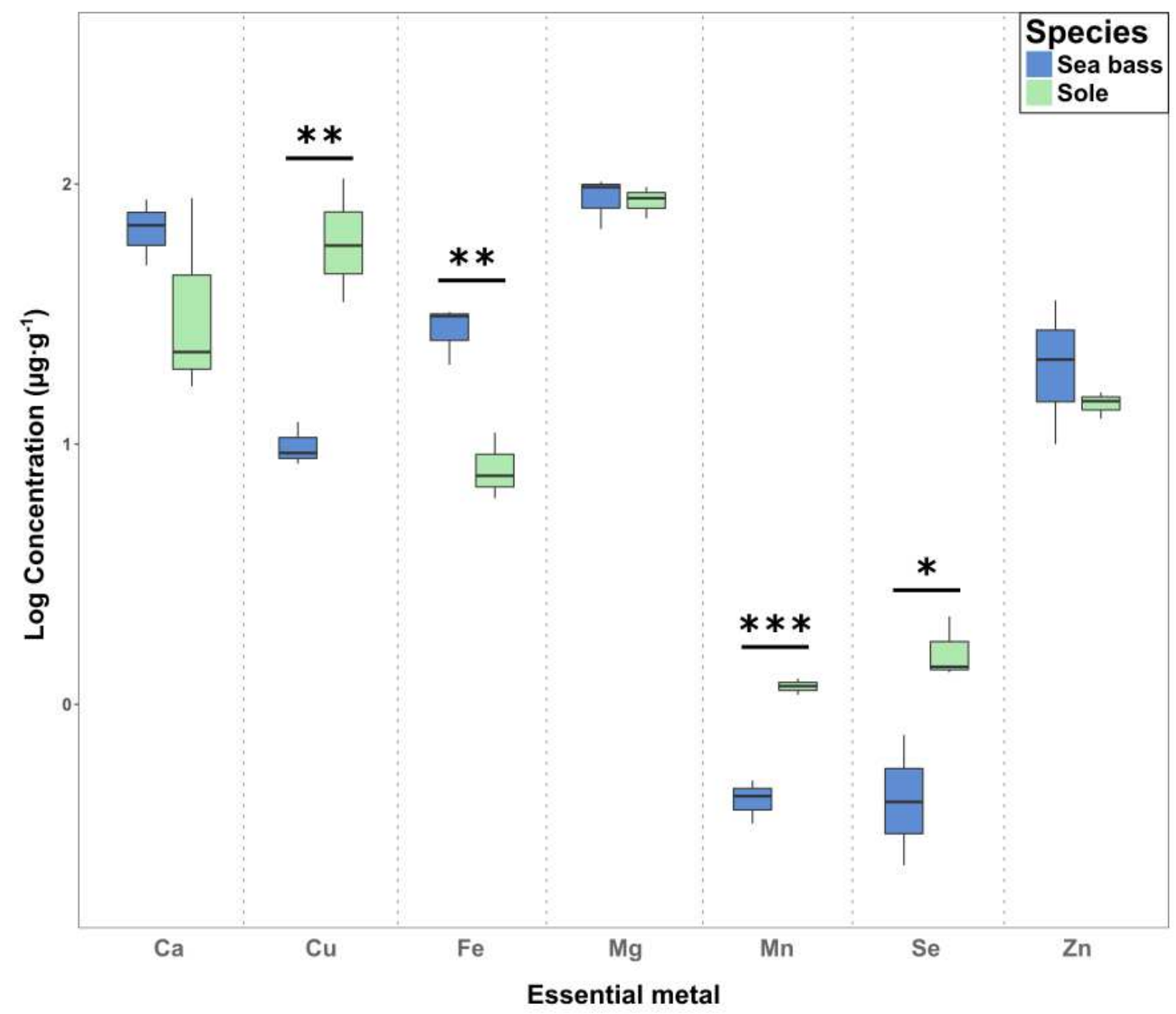

Figure 3: Total essential metal concentrations (log transformed values, $\mu \mathrm{g} \cdot \mathrm{g}^{-1} \mathrm{dw}$ ) in the liver of sea bass Dicentrachus labrax and Senegalese sole Solea senegalensis after 60 days of dietary Cd exposure $(n=3)$. Significant differences between species (ANOVA) are indicated by * $p<0.05, * * p<0.01, * * * p<$ 0.001 . No differences were found in total essential metal concentrations between control and exposed fish of the same species (see Supporting Information). 


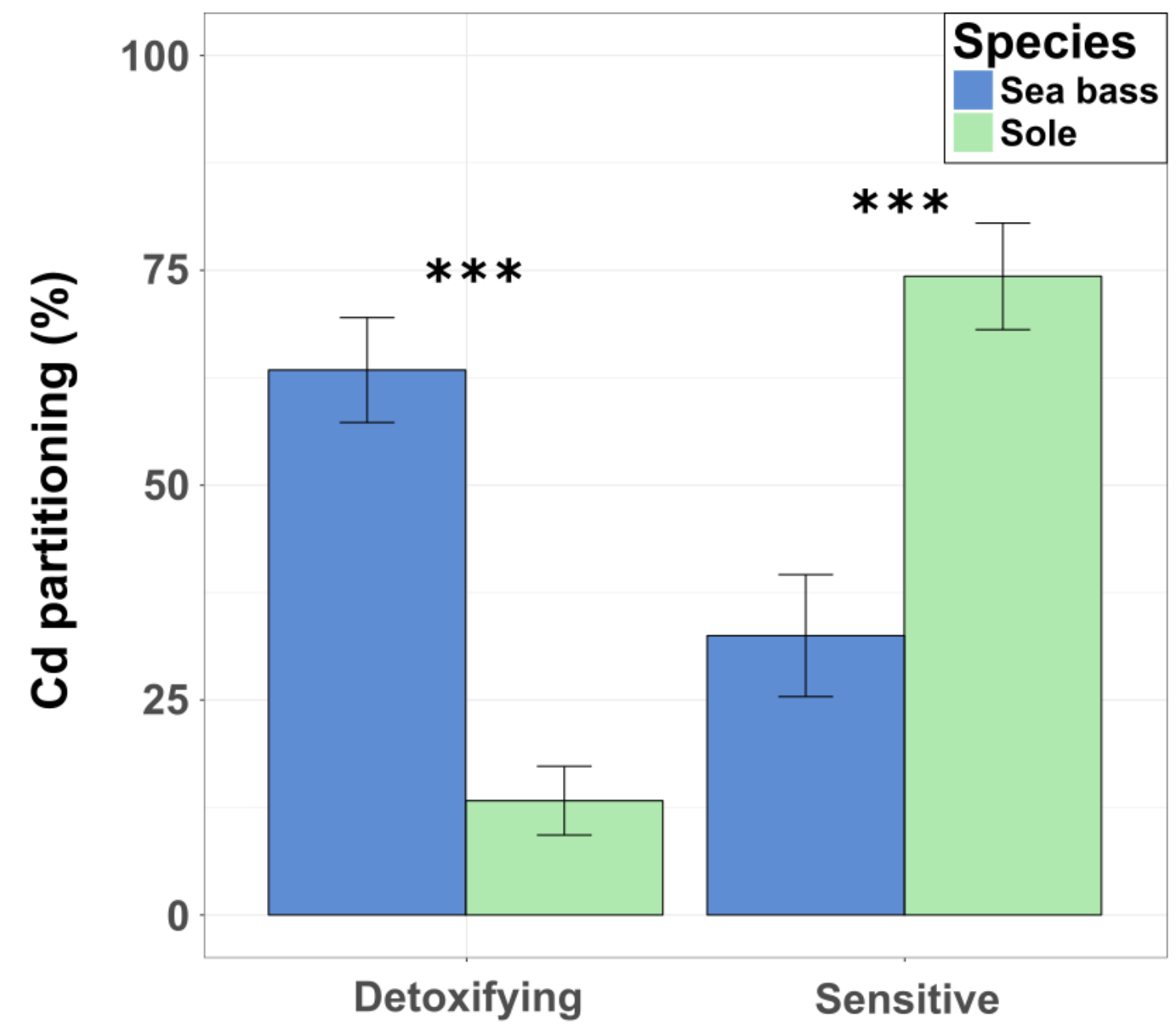

\section{Subcellular fractions}

Figure 4: Subcellular partitioning (\% of the Cd contained in each fraction type, mean \pm sd) of Cd after 60 days of depuration in the liver of sea bass Dicentrarchus labrax and Senegalese sole Solea senegalensis $(n=3)$. Sensitive fractions = mitochondria + HDP + organelles; detoxifying fractions = MRG + HSP. Significant differences between species (ANOVA) are indicated by *** $p<0.001$. 


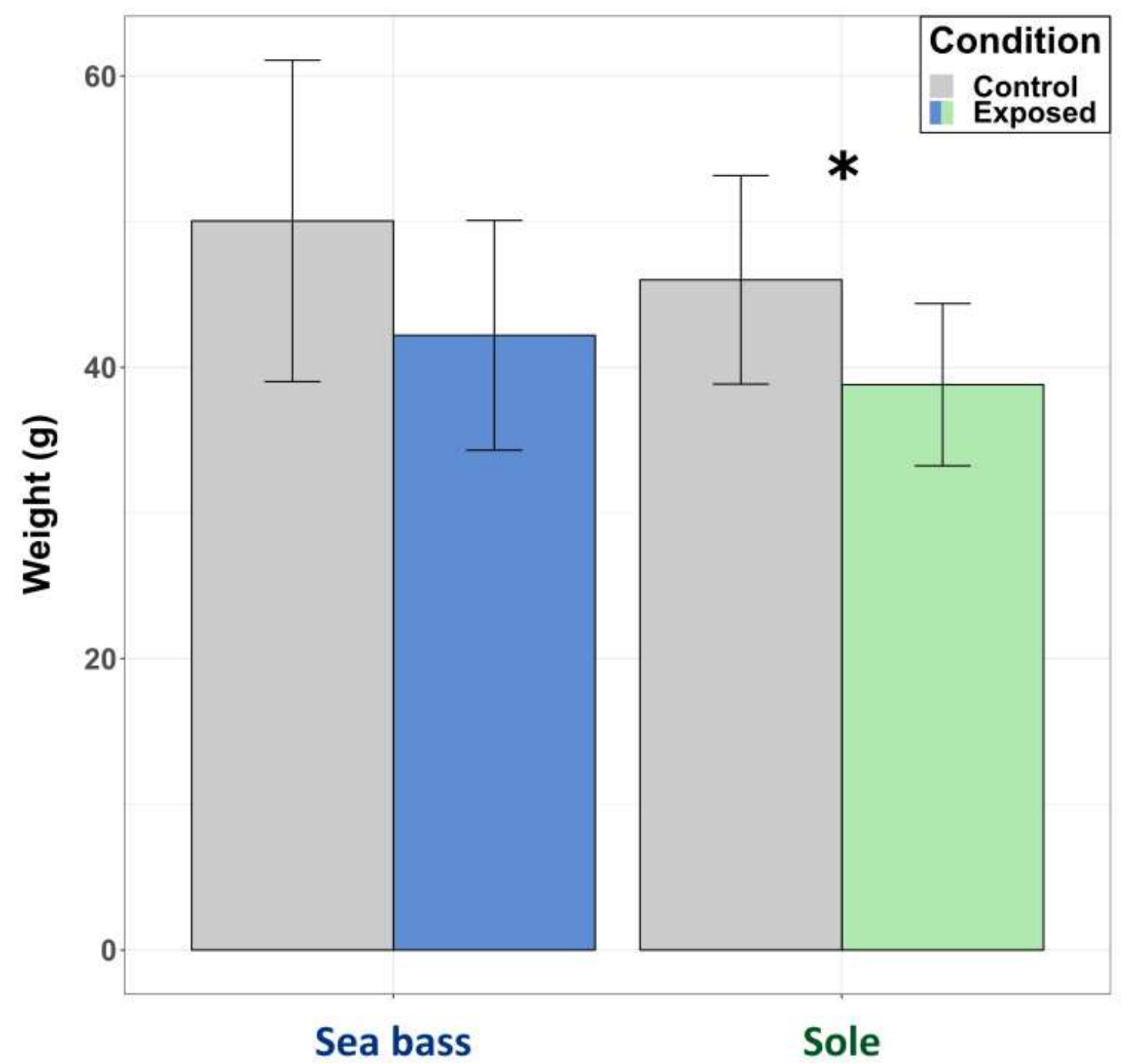

Figure 5 : Weight ( $\mathrm{g}$ ) (mean $\pm \mathrm{sd}$ ) of sea bass Dicentrarchus labrax and Senegalese sole Solea senegalensis after 60 days of Cd dietary exposure for both treatments (exposed and control fish, $n=3$ ). Significant differences between conditions (ANOVA) are indicated by * $p<0.05$. 


\section{HIGHLIGHTS}

- Sea bass and sole displayed different Cd subcellular partitioning in the liver

- Cd was largely bound to metallothionein-like proteins in the sea bass liver

- Cd was mainly linked to metal rich granules in the sole liver

- Essential metals followed the Cd partitioning pattern in hepatic cells

- Handling strategies might account for sensitivity and Cd excretion 